RECEIVED BY TIC JUN 261972

\title{
ISOTOPE KILOWATT PROGRAM QUARTERLY PROGRESS REPORT PERIOD ENDING MARCH 31, 1972
}
A. P. Fraas
G. Samuels

MASTER 


\section{DISCLAIMER}

This report was prepared as an account of work sponsored by an agency of the United States Government. Neither the United States Government nor any agency Thereof, nor any of their employees, makes any warranty, express or implied, or assumes any legal liability or responsibility for the accuracy, completeness, or usefulness of any information, apparatus, product, or process disclosed, or represents that its use would not infringe privately owned rights. Reference herein to any specific commercial product, process, or service by trade name, trademark, manufacturer, or otherwise does not necessarily constitute or imply its endorsement, recommendation, or favoring by the United States Government or any agency thereof. The views and opinions of authors expressed herein do not necessarily state or reflect those of the United States Government or any agency thereof. 


\section{DISCLAIMER}

Portions of this document may be illegible in electronic image products. Images are produced from the best available original document. 
This report was prepared as an account of work sponsored by the United States Government. Neither the United States nor the United States Atomic Energy Commission, nor any of their employees, nor any of their contractors, subcontractors, or their employees, makes any warranty, express or implied, or assumes any legal liability or responsibility for the accuracy, completeness or usefulness of any information, apparatus, product or process disclosed, or represents that its use would not infringe privately owned rights. 


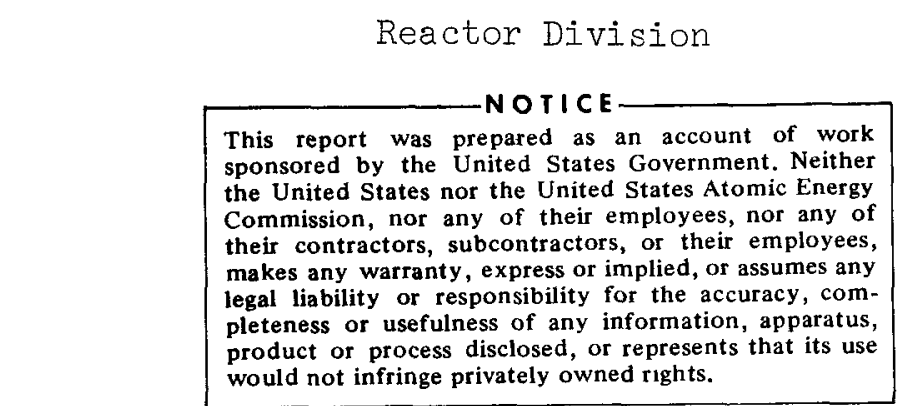

ISOTOPE KILOWATT PROGRAM QUARTERLY PROGRESS REPORT FOR PERIOD ENDING MARCH 31, 1972
A. P. Fraas, Program Director
G. Samuels, Associate Director

JUNE 1972

NOTICE This document contains information of a preliminary nature and was prepared primarily for internal use at the Oak Ridge National Laboratory It is subject to revision or correction and therefore does not represent a final report

\footnotetext{
OAK RIDGE NATIONAL IAABRATORY

Oak Ridge, Tennessee 37830

operated by

UNION CARBIDE CORPORATION

for the

U.S. ATOMIC ENERGY COMMISSION
} 
FOREWORD

In 1968 the Oak Ridge National Laboratory started work on a program to evaluate various types of radioisotope energy conversion systems for the production of 1 to $10 \mathrm{~kW}$ of electric power for terrestrial and undersea applications. This program is being carried out for the U.S. Atomic Energy Commission Division of Reactor Development and Technology and the Naval Facilities Engineering Command. The first phase of the program was a parametric and engineering analysis comparing the principal isotope fuels and the principal types of energy conversion system that have been proposed for applications of this sort, and the preparation of a set of conceptual designs for the more attractive systems. That work was completed in the summer of 1969 and was reported in Ref. 1. In October of 1969 ORNI was asked to proceed with a detailed engineering study of the three most promising systems selected from those covered in Phase I of the program. These three systems now under study are a $2-k W(e)$ thermoelectric system, a 3-kW(e) steam Rankine cycle system, and a 5-kW(e) organic Rankine cycle system.

The first step in the effort was to evolve a program plan for a three-year effort to be carried out in calendar years 1970, 1971, and 1972. The conceptual designs presented in Task I were reexamined and possible improvements were considered with particular attention to the difficult development problems. A variety of engineering tests was considered as a means of evaluating the technology, solving the principal technical problems, and investigating engineering uncertainties that should be resolved before settling on the design of a prototype power plant. In view of the limited funds and the desirability of narrowing the field to a single Rankine cycle system, particular attention was given to the relative merits of the steam and organic Rankine cycle systems.

The first quarter of 1970 was devoted to firming up reference designs for the three types of system, selecting the most crucial experiments required to evaluate the technology, and settling on a program plan for the three-year effort. ${ }^{2}$ With this first quarter's work as a foundation, the second quarter was then devoted to firming up the details of the reference designs, firming up details of the experiments to be conducted, and 
preparation of topical reports covering the three reference designs with their associated experiments. ${ }^{3}$ The subsequent quarters have been devoted to the design and construction of the most urgent experiments $4,5,6,7,8,9$ The remaining period will be devoted to the design and construction of additional test equipment and to tests designed to investigate vital questions in the technology. As the results of these tests become available, the reference designs will be revised accordingly. The objective is to evolve by December 1972 a set of designs for two prototype power plants with a clear delineation of the development program required in each case including firm estimates of the cost and time for the various programmatic steps.

This is the ninth in a series of quarterly progress reports. Topical reports present the work carried out in particular areas when key tasks are completed. When a topical report is issued essentially concurrently with a quarterly report, to avoid duplication only a very brief summary of its contents is included in the quarterly. 
CONTENTS

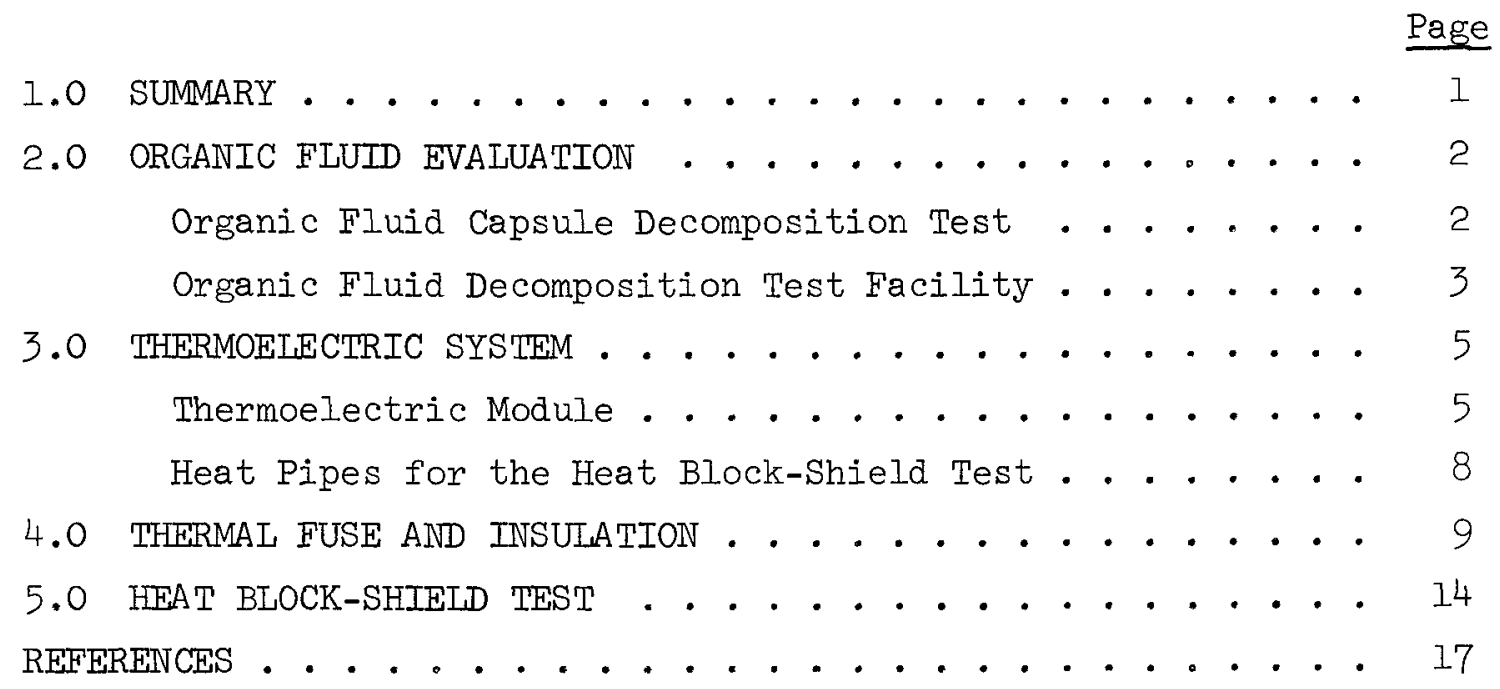




\section{ISOTOPE KILOWATT PROGRAM QUARTERLY PROGRESS REPORT}

FOR PERIOD ENDING MARCH 31, 1972

\subsection{SUMMARY}

The organic fluid capsule test continued through the quarter without incident. The total operating time at the end of March was 10,685 hr, of which $3600 \mathrm{hr}$ has been accumulated since replacement of four capsules in November.

The final results of the chemical analysis of the four capsules removed after $7000 \mathrm{hr}$ show very little decomposition or gas evolution and are very close to those predicted in the organic Rankine cycle reference report (ORNI-TM-2960).

Construction of the quarter-scale organic fluid decomposition test loop is nearly completed. The major problem now looming is procurement of sufficiently high purity Dowtherm A. The best sample submitted by Dow Chemical appears to have $300 \mathrm{ppm}$ of an unknown impurity which might conceivably be a fluorocarbon. Efforts to resolve this problem are underway.

The thermoelectric module test continued until March 19 at which time a total of $4989 \mathrm{hr}$ of continuous operation had been accumulated. The unit was shut down to permit repair of an argon leak that developed over a period of several months. This was in the instrument header and increased to the point where repressurization was required every few days. The repair will be done with epoxy resin supplied by $3 \mathrm{M}$.

The twelve heat pipes for use in the heat block-shield test have been charged with potassium, and will be thoroughly outgassed in a vacuum furnace.

The thermal conductivity tests on the 1/4-scale heat block thermal insulation rig were completed. The results showed a somewhat higher thermal conductivity at higher temperatures than the earlier data.

The meltdown test using the quarter-scale heat block test rig was carried out to determine the meltdown characteristics of the alternate foil-aluminum screen thermal insulation. The peak temperature reached in the test was $1514^{\circ} \mathrm{F}$ after $9.92 \mathrm{hr}$ of operation. Inspection of the melted material after the test indicated that even with the nitrogen gas rather 
than air in the evacuated vessel there was sufficient oxide formation to inhibit the meltdown of both the screen and the foil.

Tests of the full-scale heat block-shield temperature distribution have been completed. The results agree closely with those predicted analytically in Ref. 10. A topical report covering the entire task has been drafted. Typing of this rough draft report should be completed early in April, and should be issued within a few weeks of this quarterly report.

As a consequence of FY 1973 budget considerations in Washington, work on the full-scale organic Rankine cycle system was terminated. The design work was largely completed and procurement had been initiated, but no firm orders had been placed.

\subsection{ORGANIC FLUID EVALUATION}

\section{Organic Fluid Capsule Decomposition Test}

This facility continues to operate without difficulty at $600^{\circ} \mathrm{F}$. The elapsed time since the test was restarted after four specimens were removed for examination is now $3600 \mathrm{hr}$, and the total operating time is $10,685 \mathrm{hr}$.

Analysis of the four test capsules removed from the test stand after $7085 \mathrm{hr}$ of operation at $600^{\circ} \mathrm{F}$ was completed. The four samples all contained Dowtherm A and stainless steel wires. Two of the capsules (No. 12 and No. 15) were located in a hole $8 \mathrm{in}$. from the $\mathrm{SrTiO}_{3}$ radiation source and the other two capsules (No. 23 and No. 27) were located $11 / 4$ in. from the source.

The analysis of the liquid in all four samples was compared to a blank which had been loaded at the same time but was not exposed to the elevated temperature or irradiation. This blank showed approximately 13 ppm of benzene. The liquid in the four test samples showed the major impurity to be benzene which had increased approximately 40 to $60 \mathrm{ppm}$. Several smaller amounts of degradation products were also found but have not positively been identified.

The total of the unidentified products in each sample was in the order of 50 to $60 \mathrm{ppm}$ which was comparable to the benzene increase. The increase in benzene for each sample is shown in Table 1. 
Table 1. Results of Liquid Analysis for Benzene

\begin{tabular}{llll} 
Sample No. & Final Concentration & Blank & Increase \\
\cline { 2 - 3 } & $63 \mathrm{ppm}$ & $13 \mathrm{ppm}$ & $50 \mathrm{ppm}$ \\
No. 12 & $56 \mathrm{ppm}$ & $13 \mathrm{ppm}$ & $43 \mathrm{ppm}$ \\
No. 15 & $73 \mathrm{ppm}$ & $13 \mathrm{ppm}$ & $60 \mathrm{ppm}$ \\
No. 23 & $75 \mathrm{ppm}$ & $13 \mathrm{ppm}$ & $62 \mathrm{ppm}$ \\
No. 27 & & &
\end{tabular}

Results of the analysis on the gas removed from each sample are shown in Table 2.

Table 2. Results of Gas Analysis

\begin{tabular}{lcccc} 
& Sample No. 12 & Sample No. 15 & Sample No. 23 & Sample No. 27 \\
\cline { 2 - 3 } $\mathrm{Gas} \mathrm{vol.} \mathrm{cc(STP)}$ & 0.0685 & 0.0820 & 0.0537 & 0.0666 \\
$\mathrm{H}_{2}$ & $86.5 \%$ & $81.4 \%$ & $69.9 \%$ & $73.9 \%$ \\
$\mathrm{CH}_{4}$ & $4.3 \%$ & $4.7 \%$ & $7.5 \%$ & $4.9 \%$ \\
$\mathrm{H}_{2} \mathrm{O}$ & $0.4 \%$ & $0.6 \%$ & $0.9 \%$ & $0.5 \%$ \\
$\mathrm{Hydrocarbons}$ & $0.3 \%$ & $2.2 \%$ & $2.8 \%$ & $2.9 \%$ \\
$\mathrm{~N}_{2}+$ co & $8.1 \%$ & $8.0 \%$ & $13.9 \%$ & $11.8 \%$ \\
$\mathrm{O}_{2}$ & $>0.2 \%$ & $>0.1 \%$ & $0.2 \%$ & $>0.1 \%$ \\
$\mathrm{CO}_{2}$ & $0.2 \%$ & $3.1 \%$ & $4.8 \%$ & $6.0 \%$
\end{tabular}

Organic Fluid Decomposition Test Facility

Installation of the components for the quarter-scale organic fluid system was halted at the beginning of January pending programmatic decisions in Washington concerned with the FY 1973 budget. Work was resumed in the latter part of February. Most of the installation had been completed by the end of March and preparations are being made to vacuum leak check the system before installing heaters, thermocouples, and insulation. Efforts to resolve the differences in the amount of impurities found in the Dowtherm A by the techniques used at ORNL and the Dow Chemical Company have not been sucessful and it appears we may not have the necessary Dowtherm A material before the test facility is complete. The analytical chemistry group is presently trying to separate and identify the 
major impurity which is present to the extent of $~ 300 \mathrm{ppm}$. The chemistry group has also rechecked the various types of Dowtherm $A$ which we have used and the unidentified impurities found in the material submitted by Dow Chemical Company have been labeled Peak A and Peak B. A comparison of the analysis of the various materials, based on an average of at least two samples of each type of material, is listed below.

A. Material used in the first group of capsules was ultra pure Dowtherm A produced from Eastman Kodak products. Total of all impurities except Peak A 14 ppm and Peak $B$

Peak A

Not detected

Peak B Not detected

Total. $14 \mathrm{ppm}$

B. First material submitted by Dow Chemical Company and that used in the second set of capsules.

Total of all impurities except Peak A 25 ppm and Peak $B$

Peak A

$9 \mathrm{ppm}$

Peak B

Total $\frac{2 \mathrm{ppm}}{36 \mathrm{ppm}}$

C. First sample of Dow Chemical Company material produced for purchase.

Total of all impurities except Peak A 23 ppm and Peak $B$

Peak A

$415 \mathrm{ppm}$

Peak B

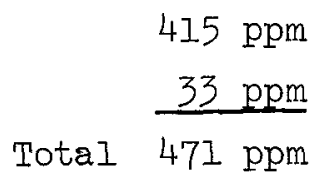

D. Second sample of Dow Chemical Company material produced for purchase. This material was submitted after further processing by Dow Chemical Company.

Total of all impurities except Peak A 20 ppm and Peak B

Peak A

Peak B

$$
\begin{array}{r}
305 \mathrm{ppm} \\
\text { Total } \frac{25 \mathrm{ppm}}{350 \mathrm{ppm}}
\end{array}
$$




\subsection{THERMOELECTRIC SYSTEM}

\section{Thermoelectric Module}

One of the most common modes of failure of a TEM is the loss of the inert atmosphere gas pressure. Fig. 1 shows the indicated pressure in the 3M generator from the time we began our tests. On January 11, 1972, the generator was repressurized to $10 \mathrm{psig}$ with argon through a valve on the instrumentation header. The argon was admitted to the TEM through a dry ice and alcohol cold trap to minimize the water content. An analysis of the argon used to repressurize the system is shown in Table 3.

Table 3. Argon Analysis

$\begin{array}{lr}\text { Argon } & 99.998 \% \\ \mathrm{O}_{2} & <0.0001(1 \mathrm{ppm}) \\ \mathrm{N}_{2}+\mathrm{CO} & 0.0005(5 \mathrm{ppm}) \\ \mathrm{CO}_{2} & <0.0001(1 \mathrm{ppm}) \\ \mathrm{H}_{2} \mathrm{O} & <0.0004(4 \mathrm{ppm}) \\ \mathrm{H}_{2} & 0.0011(11 \mathrm{ppm}) \\ \mathrm{CH}_{4} & <0.0004(4 \mathrm{ppm})\end{array}$

After the module was repressurized the apparent rate of gas loss decreased for a time. During February the rate of pressure loss increased dramatically and it became necessary to repressurize the module every few days in order to maintain a satisfactory pressure.

Figure 2 is a plot of the internal resistance of the TEM since the tests began. The small, daily, temperature cycles caused by the charging and discharging of the battery bank (shown in the previous quarterly report ${ }^{9}$ ) are the most likely cause of the steady increase in this parameter. In an attempt to determine the location of the leak on February 29, 1972, a small quantity of helium was mixed with the argon gas used to repressurize the module. A helium mass spectrometer leak detector was used to search out the leak. No evidence of any leak was found at the lower end of the unit. (Apparently the repair effected by $3 \mathrm{M}$ was still 
ORNL DWG 72-5707

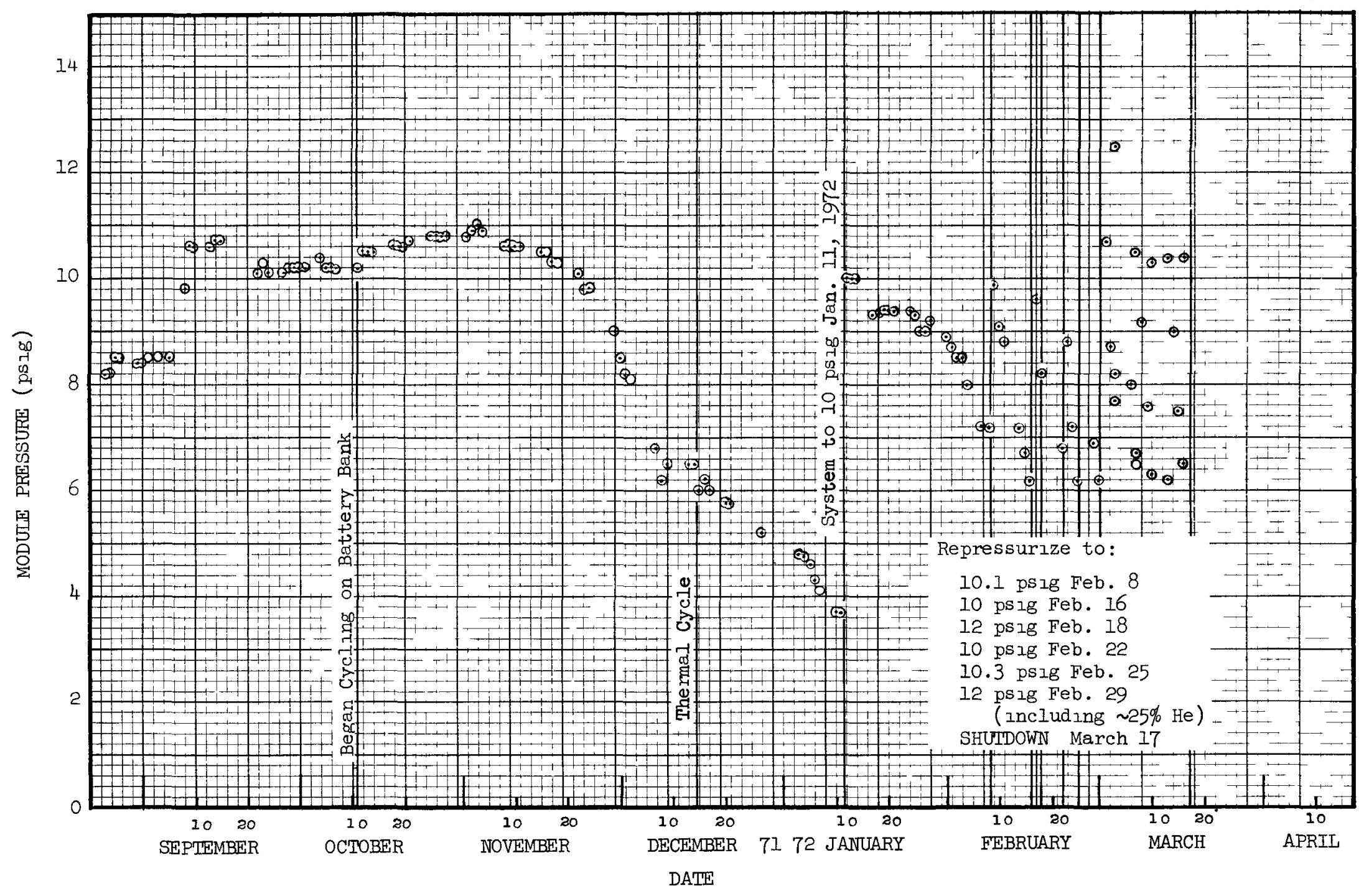

or

Fig. 1. History of gas pressure of $3 \mathrm{M}$ thermoelectric module. 


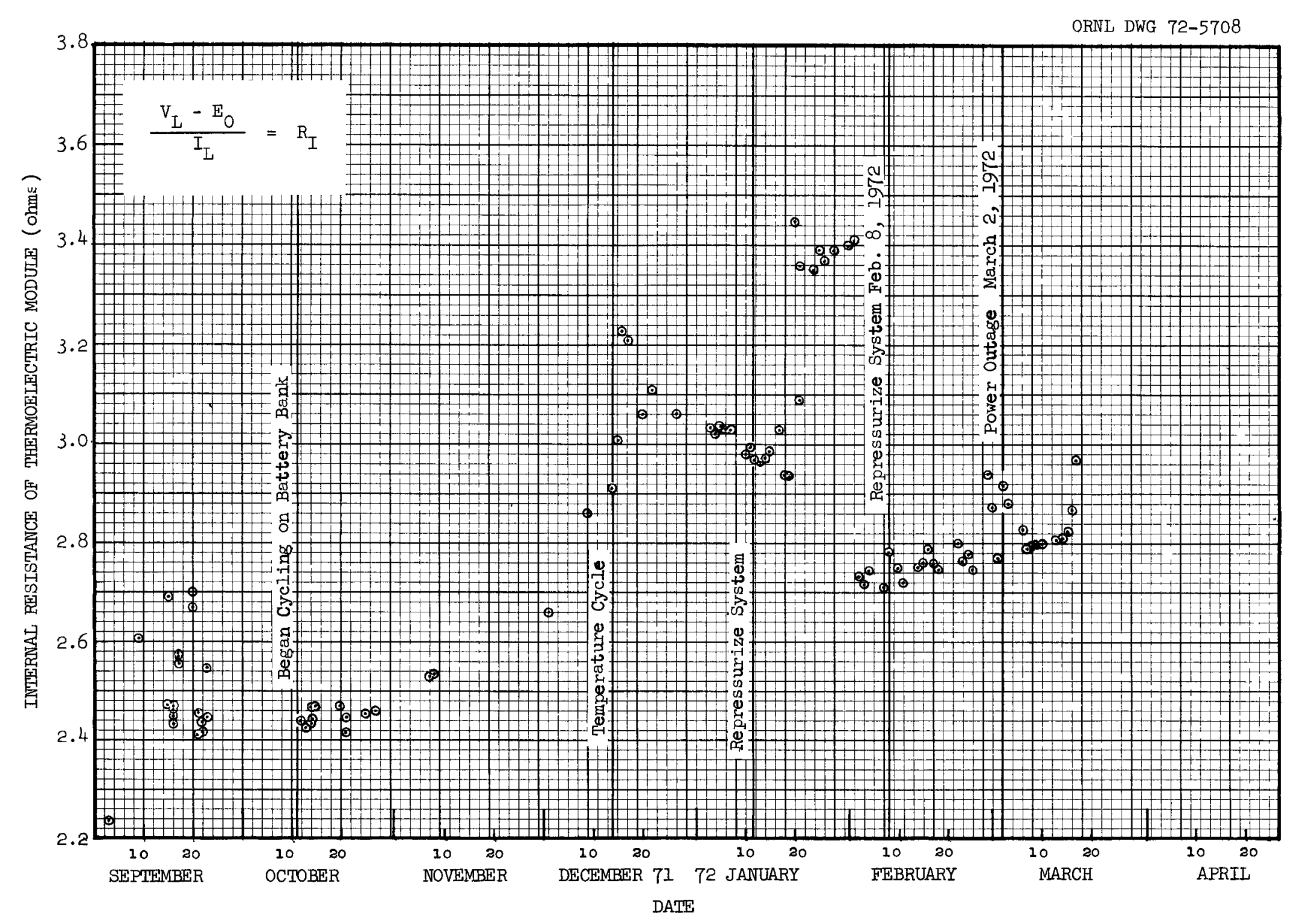

Fig. 2. History of internal resistance of $3 M$ thermoelectric module. 
holding.) There were, however, several areas on the instrument header (on the top of the module) that were leaking. Each of the leaks is associated with an electrical feed-through. The area that gave the strongest signal to the leak detector was one of the feed-throughs for the generator output. The rest of the feed-throughs all seemed to be leaking but at a slower rate.

The heat pipe-thermoelectric module continued to operate satisfactorily until March 19, 1972, when it was intentionally shut down to permit repair of the leaks that had developed in the instrument header. At the time of the shutdown the module had accumulated $4989 \mathrm{hr}$ of continuous operation.

In view of the fact that the module was covered by a one-year warranty, the 3M Company was notified of the development and asked what course of action they recommended. They suggested potting the header with plastic, and agreed to send us sufficient 3M structural adhesive to pot the instrument header .

Prior to potting the header it will be necessary to disconnect the wiring between the feed-throughs and the terminal block to provide access to the header plate for cleaning. Because, in large measure, the success or failure of this type of operation depends on the cleanliness of the surfaces involved, it is imperative that the header plate be thoroughly cleaned prior to the potting operation. After the wiring is disconnected, the header plate will be rinsed with ethyl alcohol, abrasively cleaned by grit blasting with alumina, washed with trichlorethelyene, rinsed with ethyl alcohol and distilled water, and then dried with a hot air blast.

It will be necessary to reduce the cover gas pressure inside the generator to atmospheric, or slightly below, while the potting compound is curing. It is anticipated that this shutdown will delay the module test program by about one month.

Heat Pipes for the Heat Block-Shield Test

The twelve heat pipes for this test have been fabricated, completely assembled, and are in the process of being filled with potassium. Eleven of the heat pipes will have internal hot traps and the twelfth will have an external hot trap. The first ten units will be sealed immediately after filling with potassium in the usual manner. Units eleven and twelve will 
be cold-trapped prior to sealing. (An extended section of the fill tube will act as a cold leg diffusion cold trap and will be cut off and discarded prior to sealing the heat pipe.) In the twelfth heat pipe the external hot trap is also located in a portion of the fill tube. In this instance both the hot trap and the cold trap will be discarded prior to sealing the heat pipe.

At the conclusion of the heat block-shield test it would be desirable to run some performance tests on the three types of heat pipe; ( 1 ) internal hot trap but no cold trapping done, (2) internal hot and externally cold trapped prior to sealing, and (3) externally hot trapped and cold trapped prior to sealing.

A substantial scale buildup on the heat block occurred during the initial high temperature tests. This buildup, if allowed to continue too far, might cause the heat pipes to bind in the block and make removal of the pipes difficult if not impossible without damage to the pipes. Present plans call for an initial test with twelve plain heat pipes inserted in the block. This test will be operated for a period equal to the maximum anticipated duration of the TEM-heat block test. If no difficulty is encountered in removing the plain heat pipes from the heat block after this initial test, it is safe to assume that the heat pipe with the thermoelectric generator can also be removed easily at the conclusion of their test.

\subsection{THERMAL FUSE AND INSULATION}

Thermal conductivity tests on the 1/4-scale thermal insulation test rig have been completed for the vertical position. The results are shown on the curves with the dashed lines in Fig. 3. The solid lines are the earlier results on the smaller test specimen. The new data have a steeper slope with temperature than the earlier data. 9 One possible explanation for this is that the present screen specimen was rolled more loosely than the previous specimen and has a packed density about 20 percent less than before. This may have caused an increase in the thermal conductivity by increasing the radiation heat transfer. 


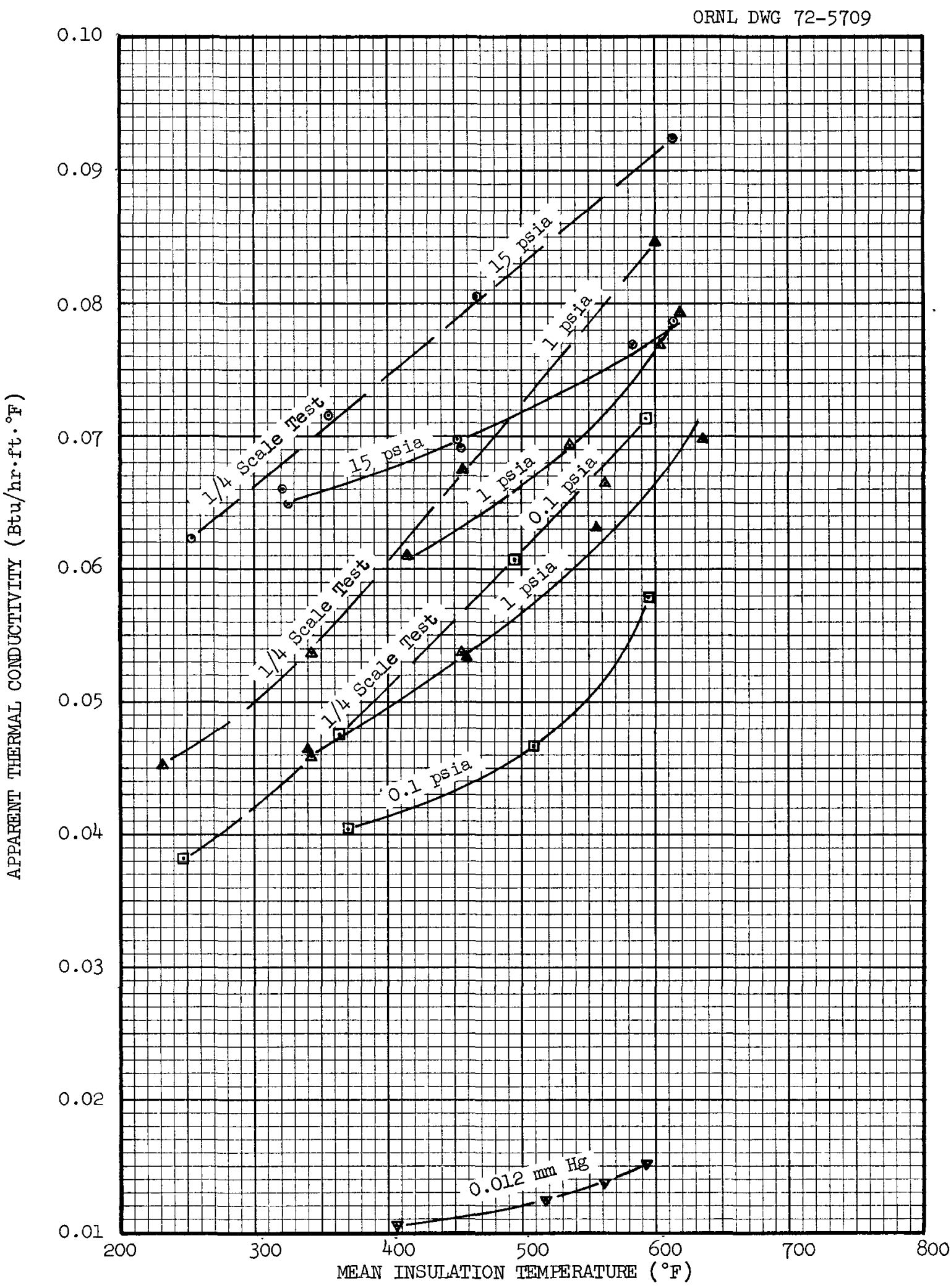

Fig. 3. Thermal conductivity vs. mean insulation temperature at reduced pressures in nitrogen of combined aluminum foil-screen insulation. 
A second insulation specimen has been fabricated for use in testing in the horizontal position. This specimen was made with a packing density about equal to that of the small-scale specimen in light of the higher thermal conductivity found with the reduced density of the present specimen.

The meltdown test for the aluminum insulation specimen in the 1/4scale insulation test rig was completed in the vertical position. The test was run at a pressure of 0.1 psia with nitrogen in the vacuum tank. The electric power input was gradually increased until a level was reached that resulted in the same surface heat flux that would exist on the full-scale heat block for the loss-of-cooling accident. The power input was adjusted so that the rate of increase of the 1/4-scale heat block surface temperature simulated the calculated rate of increase of the full-scale block surface temperature.

Temperatures at three elevations on the heat block surface were recorded continuously during the test. A plot of these temperatures is shown in Fig. 4. The highest temperature occurred at the center axial position for about $8.5 \mathrm{hr}$, whereupon the bottom temperature rose more rapidly and crossed above the top and center temperatures and reached a value of $1514^{\circ} \mathrm{F}$ at $9.92 \mathrm{hr}$. The average of the heat block temperatures was $1492^{\circ} \mathrm{F}$ at this time. The test was prematurely terminated at this point because of a short between the leads of one of the heaters resulting in the burnout of the leads and a short to the heater sheath. The heat block temperatures appeared to be leveling off, so that the temperatures at the end of the test are probably near the maximum values that would have occurred. A further indication of this is that the heater rod surface temperatures had been constant for several minutes before the heater failed. The average temperature, $1492^{\circ} \mathrm{F}$, is higher than the desired maximum temperature on the full-scale heat block, and would result in a fuel cladding temperature of about $2062^{\circ}, 62^{\circ} \mathrm{F}$ higher than the original objective.

The melted material from the thermal insulation specimen was removed from the vacuum tank for examination after the test was completed. A large quantity of molten aluminum had run from the screen and solidified in the region below the screen. See Fig. 5. The outer portion of the screen was intact with a final thickness of about 3/4 in. at the center and 1 in. at the top. The lower portion of the screen up to about $10 \mathrm{in}$. 
ORNL DWG 72-5710

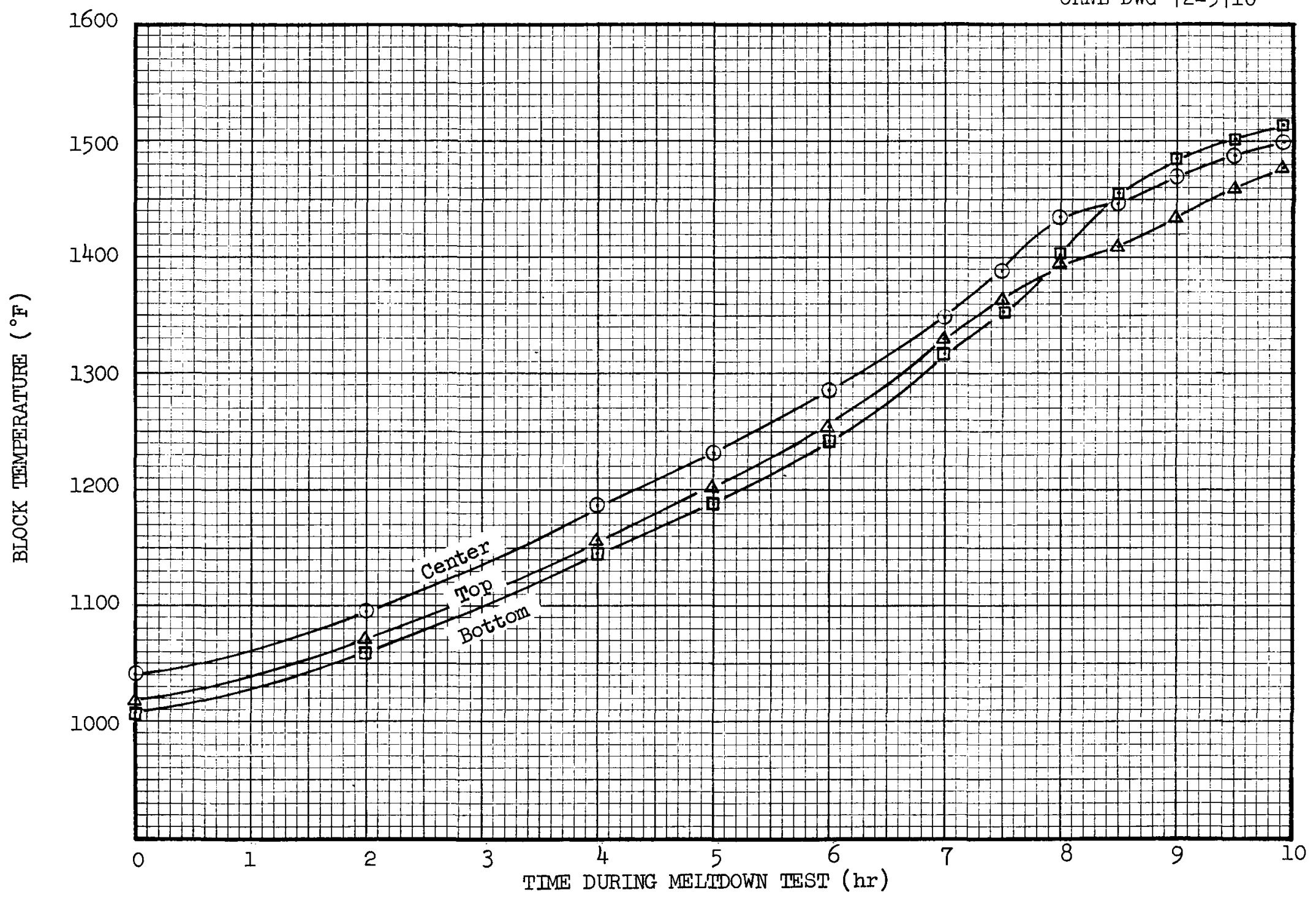

Fig. 4. Block surface temperature vs. time for vertical meltaown test on $1 / 4$-scale insulation test rig. 


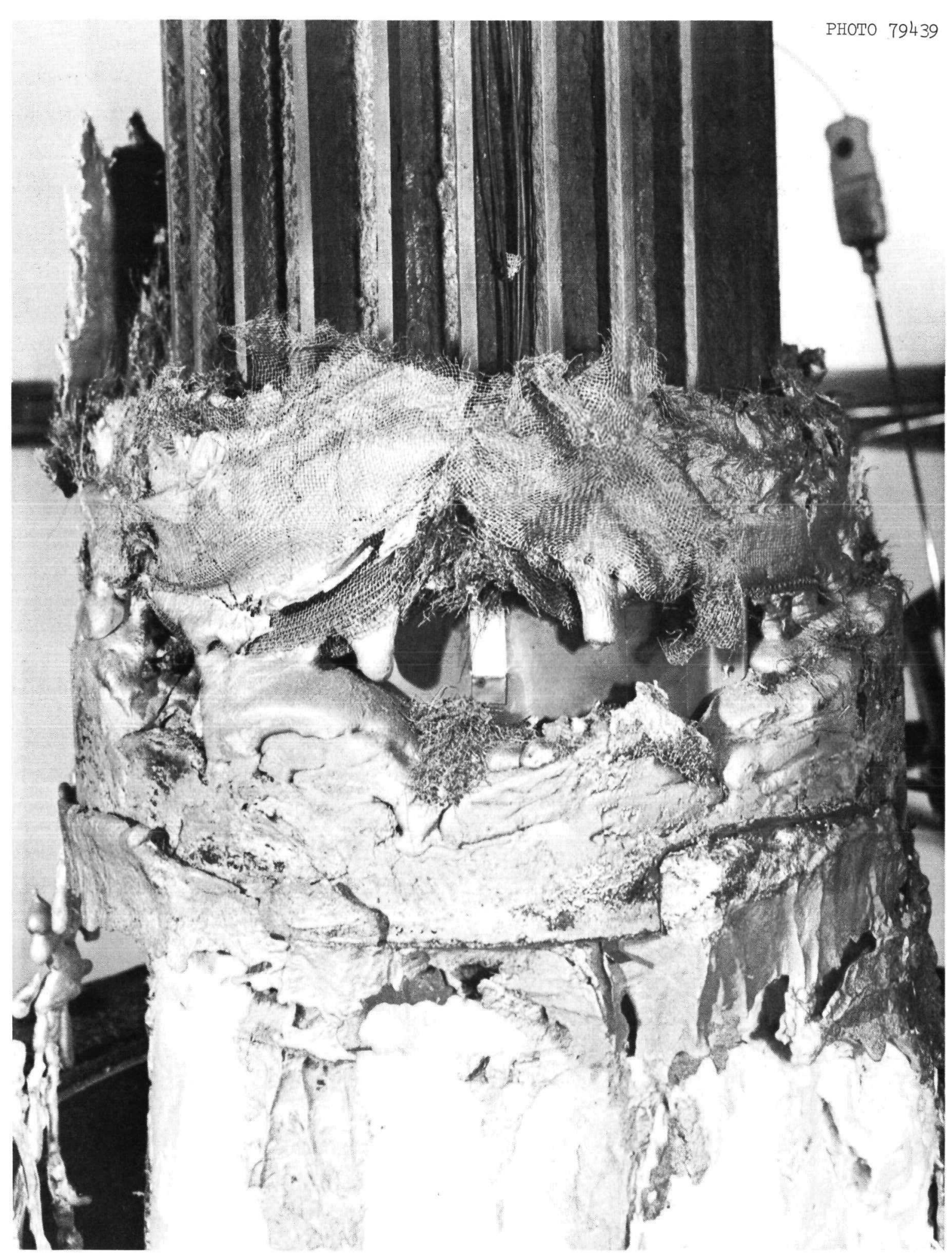

Fig. 5. Frozen aluminum collected below screen during meltdown test. 
above the bottom was packed with a mixture of metal globules and debris that had not melted. This debris consisted of a very thin transparent film from the foil and a dark gray, fragile hollow shell of the screen. The packing of this unmelted debris probably accounts for the bottom temperature exceeding the center temperature. Samples of the debris were taken to determine its composition by chemical analysis. It probably consists largely of aluminum oxide, but there is the possibility that some aluminum nitride was formed. The results of the chemical analysis should indicate whether or not the nitrogen is reacting with the aluminum. Should this be the case, consideration will be given to the use of argon as the cover gas.

\subsection{HEAT BLOCK-SHIELD TEST}

The fusible insulation for the heat block-shield was fabricated, installed, and the heat loss tests were conducted. Three points were taken at a heat block-shield surface temperature of approximately $600^{\circ} \mathrm{F}$ and pressure levels of $14.4,1.0$, and 0.1 psia. The heat losses for these three conditions were $6.82,5.67$, and $4.72 \%$ of full power, respectively.

Eight points were taken at heat block-shield surface temperatures of approximately $800^{\circ} \mathrm{F}, 900^{\circ} \mathrm{F}$, and $1100^{\circ} \mathrm{F}$, and pressure levels of 14.4 , 1.0 , and $0.1 \mathrm{psia}$. The heat losses for the various conditions are given in Table 4.

A topical reportll covering the heat block-shield tests has been nearly completed and should be ready for issue a few weeks after the issue of this quarterly progress report. 
Table 4. Heat loss from full-scale heat block-shield with three inches of fusible insulation in an air atmosphere

\begin{tabular}{ccc}
\hline $\begin{array}{c}\text { Heat Block-Shield Midplane } \\
\text { Surface Temperature } \\
\left({ }^{\circ} \mathrm{F}\right)\end{array}$ & $\begin{array}{c}\text { Pressure } \\
\text { (psia) }\end{array}$ & $\begin{array}{c}\text { Heat Loss } \\
\text { (\% of Full Power) }\end{array}$ \\
\hline 608.7 & 14.4 & 6.15 \\
593.2 & 1.0 & 5.65 \\
576.8 & 0.1 & 4.72 \\
803.6 & 14.4 & 9.92 \\
794.2 & 1.0 & 8.81 \\
804.5 & 0.1 & 8.18 \\
923.5 & 14.4 & 13.26 \\
903.8 & 1.0 & 11.38 \\
907.0 & 0.1 & 10.22 \\
1080 & 1.0 & 16.7 \\
1077 & 0.1 & 14.32 \\
\hline
\end{tabular}


REFERENCES

1. R. A. Robinson, Isotope Kilowatt Program Task 1 - Conceptual Design and Evaluation, USAEC Report ORNL-TM-2366, Oak Ridge National Laboratory, January 1970.

2. A. P. Fraas, Program Director, Isotope Kilowatt Program Quarterly Progress Report for Period Ending March 31, 1970, USAEC Report ORNL-TM-3011, Oak Ridge National Laboratory, July 1970.

3. A. P. Fraas, Program Director, Isotope Kilowatt Program Quarterly Progress Report for Period Ending June 30, 1970, USAEC Report ORNL-TM-3099, Oak Ridge National Laboratory, September 1970.

4. A. P. Fraas, Program Director, Isotope Kilowatt Program Quarterly Progress Report for Period Ending September 30, 1970, USAEC Report ORNL-TM-3214, Oak Ridge National Laboratory, December 1970.

5. A. P. Fraas, Program Director, Isotope Kilowatt Program Quarterly Progress Report for Period Ending December 31, 1970, USAEC Report ORIVL-TM-3292, Oak Ridge National Laboratory, February 1971.

6. A. P. Fraas, Program Director, Isotope Kilowatt Program Quarterly Progress Report for Period Ending March 31, 1971, USAEC Report ORNL-TM-3394, Oak Ridge National Laboratory, May 1971.

7. A. P. Fraas, Program Director, Isotope Kilowatt Program Quarterly Progress Report for Period Ending June 30, 1971, USAEC Report ORNL-TM-3491, Oak Ridge National Laboratory, August 1971.

8. A. P. Fraas and G. Samuels, Isotope Kilowatt Program Quarterly Progress Report for Period Ending September 30, 1971, USAEC Report ORNL-TM-3592, Oak Ridge National Laboratory, November 1971.

9. A. P. Fraas and G. Samuels, Isotope Kilowatt Program Quarterly Progress Report for Period Ending December 30, 1971, USAEC Report ORNL-TM-3687, Oak Ridge National Laboratory, April 1972.

10. G. Samuels, Comparison of Nickel and Iron Heat Block-Shields, USAEC Report ORNL-TM-3213, Oak Ridge National Laboratory, January 1971.

II. M. E. Lackey, Thermal Test of the Heat Block-Shield for the Isotope Kilowatt Program, USAEC Report ORNL-TM-3806, Oak Ridge National Laboratory, to be published. 
ORNL TM 3805

Internal Distribution

1. S. E. Beall
2. T. A. Butler
3. W. B. Cottrell
4. W. C. Cox
5. F. L. Culler
6. R. G. Donnelly
7-16. A. P. Fraas
17. J. H. Frye, Jr.
18. J. H. Gillette
19. A. G. Grindell
20. K. W. Haff
21. H. W. Hoffman
22. R. S. Holcomb
23. P. R. Kasten
24. M. E. Lackey
25. E. Lamb
26. M. E. LaVerne
27. D. B. Lloyd
28. M. I. Lundin
29. R. N. Lyon
30. R. E. MacPherson
31. H. C. McCurdy
32. A. J. Miller

\author{
33. A. M. Perry \\ 34. R. A. Robinson \\ 35. M. W. Rosenthal \\ 36. A. F. Rupp \\ 37-46. G. Samuels \\ 47. Myrtleen R. Sheldon \\ 48. A. C. Schaffhauser \\ 49. M. J. Skinner \\ 50. A. M. Smith \\ 51. I. Spiewak \\ 52. D. A. Sundberg \\ 53. D. B. Trauger \\ 54. J. J. Tudor \\ 55. A. M. Weinberg \\ 56. G. D. Whitman \\ 57. J. V. Wilson \\ 58. H. C. Young \\ 59. Biology Library \\ 60-61. Central Research Library \\ 62. Y-12 Document Reference Section \\ 63-87. Laboratory Records Department \\ 88. Laboratory Records Department (RC)
}

External Distribution

89. D. F. Cope, RDT Site Office, ORNL

90. W. M. Crim, Jr., Research and Technology Department, Building 322 , Ft. Belvoir, Virginia 22060

91. E. E. Fowler, Division of Applied Technology, AEC, Washington, D. C. 20545

92-96. W. D. Holloman, Division of Reactor Development and Technology, AEC, Washington, D. C. 20545

97-98. M. Klein, Division of Space Nuclear Systems, AEC, Washington, D. C. 20545

99. J. J. Lynch, INASA Headquarters, Washington, D. C. 20546

100. S. V. Manson, NASA Headquarters, Washington, D. C. 20546

101. R. F. Mather, NASA, Lewis Research Center, Cleveland, Ohio 44135

102. T. A. McLaughlin, Isotopic Auxiliary Power Branch, AEC, Washington, D. C. 20545

103-107. Nuclear Engineering Division, Naval Facilities Engineering Command, Washington, D. C. 20545

108. J. Pidkowicz, RDT Site Office, ORNL

109. W. B. Taylor, Technical Director, U.S. Army Mobility Equipment Research and Development Center, Ft. Belvoir, Virginia 22060 
110. E. S. Wilson, Space Nuclear Systems, AEC, Germantown, Maryland 20767

111-112. Technical Information Center, AEC

113. Laboratory and University Division, ORO

114-116. Director, Division of Reactor Licensing, AEC-Wash.

117-118. Director, Division of Reactor Standards, AEC-Wash. 